\title{
Modifying 5-HT1A receptor gene expression as a new target for antidepressant therapy
}

\author{
Paul R. Albert* and Brice Le François \\ Department of Neuroscience, Ottawa Hospital Research Institute, University of Ottawa, Ottawa, ON, Canada
}

\section{Edited by:}

Xiao-Ming Ou,

University of Mississippi Medical

Center, USA

\section{Reviewed by:}

Jason B. Wu,

University of Southern California, USA

Xiao-Ming Ou, University of Mississippi

Medical Center, USA

${ }^{*}$ Correspondence:

Paul R. Albert,

Department of Neuroscience, Ottawa

Hospital Research Institute, University

of Ottawa, 451 Smyth Road, Ottawa,

ON K1H-8M5, Canada.

e-mail:palbert@uottawa.ca
Major depression is the most common form of mental illness, and is treated with antidepressant compounds that increase serotonin (5-HT) neurotransmission. Increased 5-HT1A autoreceptor levels in the raphe nuclei act as a "brake" to inhibit the $5-\mathrm{HT}$ system, leading to depression and resistance to antidepressants. Several 5-HT1A receptor agonists (buspirone, flesinoxan, ipsapirone) that preferentially desensitize 5-HT1A autoreceptors have been tested for augmentation of antidepressant drugs with mixed results. One explanation could be the presence of the $C(-1019)$ G 5-HT1A promoter polymorphism that prevents gene repression of the 5-HT1A autoreceptor. Furthermore, down-regulation of 5-HT1A autoreceptor expression, not simply desensitization of receptor signaling, appears to be required to enhance and accelerate antidepressant action. The current review focuses on the transcriptional regulators of 5-HT1A autoreceptor expression, their roles in permitting response to 5-HT1A-targeted treatments and their potential as targets for new antidepressant compounds for treatment-resistant depression.

Keywords: 5-HT1A receptor, transcription, autoreceptor, major depressive disorder, serotonin receptors, raphe nuclei

\section{INTRODUCTION}

\section{DEPRESSION AND SEROTONIN}

Major depression is the most prevalent form of mental illness, twice as frequent in women as in men (Doris et al., 1999; Fava and Kendler, 2000), and is predicted to increase from fourth to second (first in high income countries) highest global burden of disease by 2030 (Ustun et al., 2004; Mathers and Loncar, 2006). There is a need for improved antidepressant treatments since only $30 \%$ of patients remit with current strategies (Trivedi et al., 2006a,b, 2008), while 15\% attempt suicide (Mann et al., 2001; Mann, 2005). Although other neurotransmitters (e.g., noradrenaline, dopamine, glutamate, neurotrophins) are indirectly involved in depression (Blier, 2003; Duman, 2004; Nestler and Carlezon Jr., 2006; Skolnick et al., 2009), multiple lines of evidence implicate reduced 5-HT neurotransmission as a primary defect in depression (Millan, 2004; Wong et al., 2005; Tremblay and Blier, 2006; Jans et al., 2007; aan het Rot et al., 2009). Virtually all antidepressant treatments, including serotonin reuptake inhibitors (SSRIs), increase 5-HT neurotransmission, either directly or indirectly (Blier, 2003; Berton and Nestler, 2006; Savitz et al., 2009).

\section{5-HT1A RECEPTORS AND THE 5-HT SYSTEM}

The brain serotonin (5-HT) system originates from neurons of the raphe nuclei that express tryptophan hydroxylase 2 (TPH2), the ratelimiting enzyme for 5-HT synthesis (Walther et al., 2003). These neurons project widely throughout the brain (Hornung, 2003) to regulate many physiological functions, including sleep, mood and stress reactivity and are implicated in mental illnesses, including MDD and anxiety (Barnes and Sharp, 1999; Young and Leyton, 2002; Gordon and Hen, 2004; Lanfumey et al., 2008; Savitz et al., 2009). Among the 17 human 5-HT receptor genes, we have focused on the 5-HT1A receptor since it is abundant in corticolimbic regions that are implicated in mood and emotion (Albert et al., 1996; Albert and Lemonde, 2004). The 5-HT1A receptor also functions presynaptically as the major somatodendritic autoreceptor on 5-HT neurons (Sotelo et al., 1990; Riad et al., 2000) where it acts as a "brake" to inhibit the activity of the entire 5-HT system (Hjorth et al., 1996; Richer et al., 2002; Bortolozzi et al., 2004) (Figure 1). Hence, the mechanisms that regulate 5-HT1A autoreceptor levels set the tone of the 5-HT system.

\section{5-HT1A RECEPTORS IN DEPRESSION 5-HT1A RECEPTORS IN ANIMAL MODELS OF DEPRESSION}

Despite their limited validity to model human depression, animal behavioral studies have provided valuable insights into the biological function of 5-HT1A receptors in depression and anxiety. Importantly, 5-HT1A-null mice display increased anxiety behavior (Heisler et al., 1998; Parks et al., 1998; Ramboz et al., 1998) and are unresponsive to SSRI treatment (Santarelli et al., 2003), while early developmental overexpression of the 5-HT1A receptor decreases anxiety (Kusserow et al., 2004). 5-HT1A receptor expression in early postnatal forebrain of 5-HT1A-/- mice rescues the anxiety phenotype, suggesting that post-synaptic 5-HT1A receptors are critical in the development of the anxiety phenotype (Gross et al., 2002). Conversely, mice with a $30 \%$ increase in 5-HT1A autoreceptors display reduced 5-HT neuron firing, reduced 5-HT release, increased depression behavior, but no change in anxiety behavior (Richardson-Jones et al., 2010). Hence, while reduction in postsynaptic 5-HT1A receptors is implicated in anxiety, increased levels of presynaptic 5-HT1A autoreceptors inhibit 5-HT neurotransmission and leads to depression (Figure 1).

\section{5-HT1A RECEPTORS IN CLINICAL DEPRESSION}

In human depression, there remain conflicting findings concerning changes in 5-HT1A binding potential (Savitz et al., 2009). Most studies find reductions in post-synaptic 5-HT1A receptors in subsets of prefrontal and temporal cortical regions in depression (Sargent et al., 2000; Bhagwagar et al., 2004; Shively et al., 2006; Moses-Kolko 


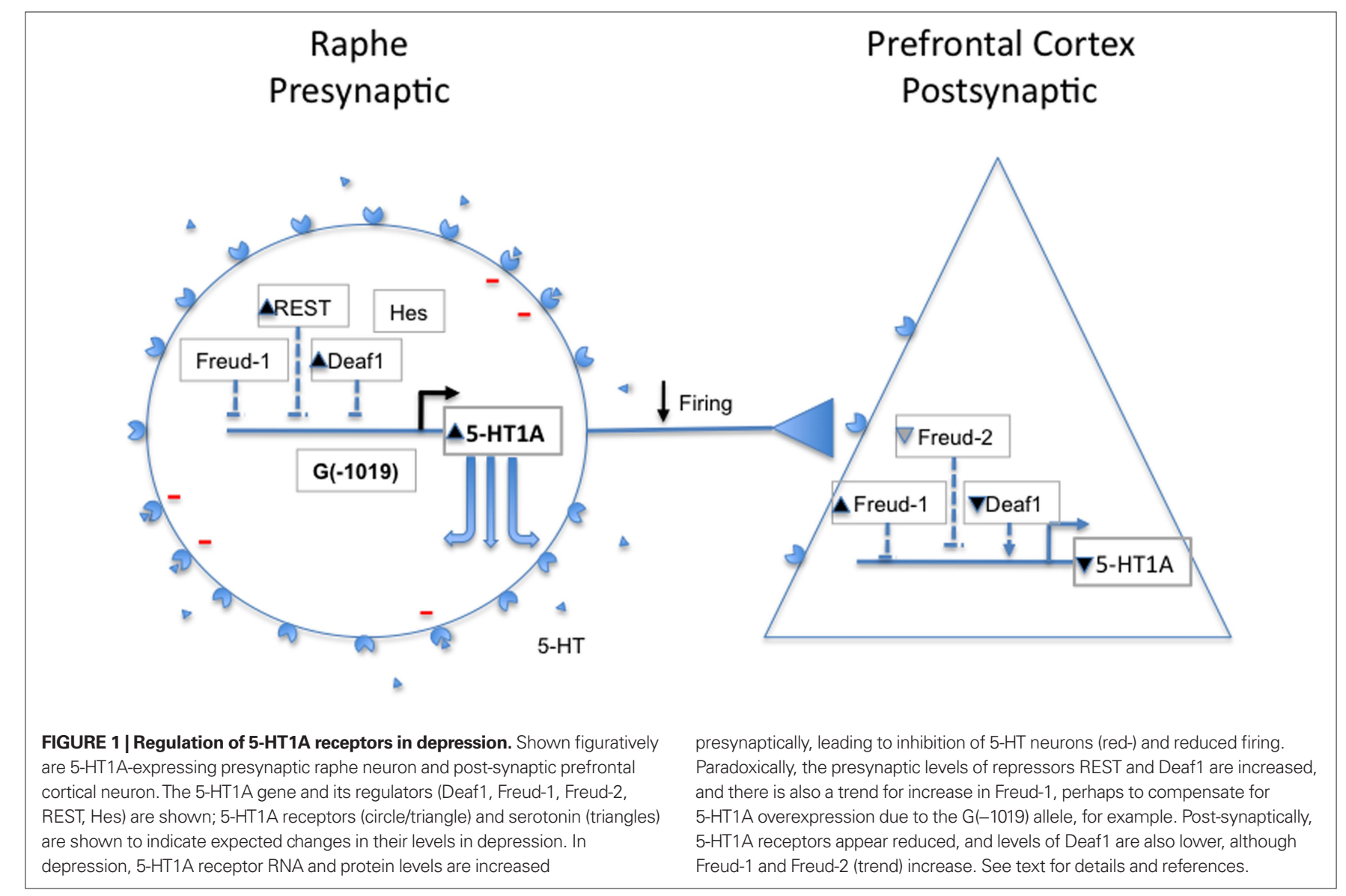

et al., 2008) and anxiety (Tauscher et al., 2001; Neumeister et al., 2004; Sullivan et al., 2005; Lanzenberger et al., 2007; Nash et al., 2008; Akimova et al., 2009). In contrast, 5-HT1A autoreceptors are increased in depressed patients (Parsey et al., 2006a,b) and in postmortem raphe tissue from depressed suicide victims (Stockmeier et al., 1998; Boldrini et al., 2008). However, decreases in raphe 5-HT1A binding have also been reported, but may reflect a reduction in 5-HT neurons (Drevets et al., 2007). These region-specific alterations in 5-HT1A receptor levels in depression are consistent with a global reduction in 5-HT neurotransmission, since increased 5-HT1A autoreceptors reduce 5-HT neuronal activity, while reduced post-synaptic 5-HT1A receptors reduce behavioral response to 5-HT (Albert and Lemonde, 2004).

\section{5-HT1A RECEPTORS IN ANTIDEPRESSANT RESPONSE}

Although SSRIs rapidly enter the brain and block 5-HT reuptake, chronic 3-week treatment is required for clinical response, due to recurrent inhibition of raphe activity by 5-HT1A autoreceptors (Figure 1). During this period, 5-HT1A autoreceptors desensitize (Le Poul et al., 1995; Mochizuki et al., 2002; Shen et al., 2002; Elena Castro et al., 2003), leading to reduced 5-HT1A RNA and autoreceptor levels, particularly in animal models of depression and depressed subjects (Welner et al., 1989; Fanelli and McMonagle-Strucko, 1992; Sibug et al., 1998; Le Poul et al., 2000; Meltzer et al., 2004; Rabiner et al., 2004; Berney et al., 2008), resulting in restoration of raphe firing activity and 5-HT release. Chronic antidepressant treatment reverses changes in 5-HT1A receptor RNA expression in chronic stress models (Burnet et al., 1995; Greenwood et al., 2003, 2005; Morley-Fletcher et al., 2004), as well as in depression (Lopez et al., 1998; Lopez-Figueroa et al., 2004). However, several studies in "normal" animals have found that chronic antidepressant treatments desensitize 5-HT1A receptors without a concomitant reduction in receptor levels (Le Poul et al., 1995; Elena Castro et al., 2003; Rossi et al., 2008). Because acute desensitization (uncoupling and internalization) occurs rapidly (second-minute) and is reversible (Riad et al., 2001, 2004), we postulated that acute desensitization is not sufficient for antidepressant response, but that a reduction in the synthesis of new 5-HT1A receptors may be required, and could account for the longer time course of the treatment (Albert et al., 1996; Albert and Lemonde, 2004). Interestingly, a 30\% reduction in 5-HT1A autoreceptors is sufficient to permit a rapid and robust response to chronic SSRI treatment in mice that do not otherwise respond (Richardson-Jones et al., 2010), suggesting that transcriptional down-regulation of the 5-HT1A mRNA could be a key mechanism in determining antidepressant response.

\section{TRANSCRIPTIONAL REGULATION OF THE 5-HT1A RECEPTOR GENE IN MENTAL ILLNESS TRANSCRIPTIONAL REGULATION OF THE 5-HT1A RECEPTOR GENE}

Based on the hypothesis that impaired repression of the 5-HT1A receptor gene may predispose individuals to depression, we have identified key transcription regulators of the 5-HT1A receptor 
(Albert et al., 1996; Albert and Lemonde, 2004). The 5-HT1A receptor gene is intronless with a non-selective CG-rich housekeeping promoter containing multiple strong Sp1/MAZ enhancers that drive expression in all cells (Albert et al., 1996; Parks and Shenk, 1996; Storring et al., 1999) and an upstream repressor region that silences its expression in non-neuronal cells, but also represses transcription in neuronal cells that express 5-HT1A receptors (Ou et al., 2000; Lemonde et al., 2004b). The promoter also contains an NFkB-response element, that may mediate 5-HT1A induction in immune cells, although its function in neurons remains unaddressed. Repressors include Freud-1/CC2D1A and Freud-2/ CC2D1B (Five-prime Repressor Element Under Dual repression binding protein), calcium-sensitive repressors of pre- (Freud-1) and post-synaptic 5-HT1A receptor expression in neurons (Ou et al., 2003; Lemonde et al., 2004b; Hadjighassem et al., 2009). We have also identified Deaf1 and Hes1/Hes5 as regulators at the $\mathrm{C}(-1019) \mathrm{G}$ 5-HT1A polymorphism that repress 5-HT1A autoreceptor transcription at the $\mathrm{C}$-allele but not the $\mathrm{G}$-allele (Lemonde et al., 2003). Consistent with this, the G/G genotype is associated increased 5-HT1A autoreceptor binding potential in depressed subjects (Parsey et al., 2006b). Deaf1 is colocalized with 5-HT1A receptors in raphe and post-synaptic neurons, and expressed from development to adulthood; while Hes proteins are restricted to neural precursors and immature neurons. In Hes1-/mice, 5-HT1A receptor RNA expression is greatly up-regulated in embryonic midbrain (Jacobsen et al., 2008), suggesting that the $G(-1019)$ allele may result in an early embryonic alteration in 5-HT1A receptor levels. Interestingly, Deaf1 displays tissuespecific activity, repressing 5-HT1A autoreceptor RNA and protein expression in raphe cells, but enhancing 5-HT1A promoter activity in non-serotonergic neurons (Lemonde et al., 2003; Czesak et al., 2006). Based on this, the G-allele is expected to increase 5-HT1A autoreceptor levels to reduce 5-HT neuronal activity, and decrease post-synaptic 5-HT1A receptors, synergistically reducing 5-HT neurotransmission.

\section{TRANSCRIPTIONAL DYSREGULATION OF THE 5-HT1A RECEPTOR GENE IN MENTAL ILLNESS}

Changes in 5-HT1A receptor RNA and protein levels are observed in brain regions of MDD subjects as discussed above, and suggest that alterations in 5-HT1A receptor gene expression could confer susceptibility. We initially associated the C(-1019)G polymorphism with MDD and suicide (Lemonde et al., 2003). This association has been replicated in most studies (Parsey et al., 2006b; Anttila et al., 2007; Kraus et al., 2007; Le François et al., 2008; Kishi et al., 2009; Neff et al., 2009). In our original study (Lemonde et al., 2003), both $\mathrm{G} / \mathrm{G}$ genotype $\left(P=0.0134^{\star}\right)$ and $\mathrm{G}$-allele frequencies $\left(P=0.0043^{\star *}\right)$ were associated with depression in females ( 81 normal; 74 depressed). Males (53 control; 55 depressed) showed the same trends for genotype and allele frequency $(P=0.0846$ and 0.0574$)$, but they were not significant, suggesting a stronger association in females. However the allele and genotype ratios in depressed/control were similar (G/G genotype frequency $2.36 \times$ and $2.39 \times$ for females and males; G-allele frequency $1.45 \times$ and $1.33 \times$ ). Hence there does not appear to be a clear gender effect of the polymorphism for association with depression.
Recently, the homozygous 5-HT1A G/G(-1019) risk genotype has been associated with increased levels of 5-HT1A autoreceptors in the raphe of depressed and bipolar depressed subjects (Parsey et al., 2006b; Sullivan et al., 2009), which is consistent with the increase in 5-HT1A autoreceptors observed in postmortem studies of depressed suicides (Stockmeier et al., 1998; Drevets et al., 2007; Boldrini et al., 2008). This association supports the hypothesis that the 5-HT1A G(-1019) allele is a risk factor for depression by increasing 5-HT1A autoreceptor levels to reduce 5-HT neurotransmission (Albert and Lemonde, 2004). Interestingly, in serotonin neurons of depressed females, RNA levels of both Deaf1 and REST [a repressor of 5-HT1A receptor transcription (Lemonde et al., 2004b)] are increased, suggesting a compensatory change to re-establish normal 5-HT1A autoreceptor levels (Goswami et al., 2010). Despite these compensatory changes, there was a trend toward increased 5-HT1A RNA levels in depressed female raphe tissue, consistent with previous studies showing increased 5-HT1A autoreceptors. The recent finding that mice with selective increase in presynaptic 5-HT1A autoreceptors have depression-like behavior and are resistant to antidepressants (Richardson-Jones et al., 2010), provides validation of the hypothesis that dysregulation of the 5-HT1A autoreceptor is implicated in major depression (Albert et al., 1996; Albert and Lemonde, 2004).

In addition to its association with depression, we and others have found that the $G(-1019)$ allele associates with reduced response to chronic SSRI or SSRI/pindolol treatment (Lemonde et al., 2004a; Le François et al., 2008; Villafuerte et al., 2009; Yevtushenko et al., 2010). Interestingly, antidepressant response to flibanserin, a 5-HT1A agonist which directly targets 5-HT1A receptor desensitization, was the most attenuated in subjects with the G/G genotype. This suggests that the Deaf1 site is critical for antidepressant action to down-regulate 5-HT1A autoreceptor expression. However, particularly in Asian populations where the G-allele is more prevalent, there is evidence that SSRI response is greater in the G/G genotype (Kato et al., 2009), suggesting that alternate regulatory factors (e.g., Freud-1, REST) could augment 5-HT1A autoreceptor down-regulation. Therefore, mechanisms preventing 5-HT1A autoreceptor de-repression could provide effective therapy for treatment-resistant depressed patients.

Thus, alterations in transcription factors that regulate 5-HT1A expression could either contribute to the dysregulation of the receptor or compensate for changes associated with mental illness.

\section{TARGETING 5-HT1A AUTORECEPTORS FOR ANTIDEPRESSANT RESPONSE TARGETING 5-HT1A AUTORECEPTORS TO AUGMENT TO ANTIDEPRESSANT EFFICACY}

Several compounds that target 5-HT1A receptors including pindolol and buspirone, have been used in augmentation with SSRIs to accelerate or enhance their antidepressant action. Pindolol is a $\beta$-adrenergic receptor blocker also shown to act as a weak partial agonist of the 5-HT1A receptor (Newman-Tancredi et al., 1998). Pindolol preferentially competes with endogenous 5-HT at presynaptic 5-HT1A receptors (Rabiner et al., 2004; Serrats et al., 2004) to increase serotonergic neurotransmission. Clinical 
studies have demonstrated that pindolol can accelerate response to SSRIs, even in drug-resistant depression (Artigas et al., 1994; Blier and Bergeron, 1995; Portella et al., 2009). However, the ability of pindolol to improve SSRI treatment has not been consistent, in part due to low occupancy of 5-HT1A receptor sites at the dose of pindolol used in most studies (Martinez et al., 2000). In contrast to pindolol, buspirone functions as strong 5-HT1A partial agonist that can specifically desensitize 5-HT1A autoreceptors (Sim-Selley et al., 2000) to relieve serotonergic autoinhibition. Similarly to pindolol, buspirone was able to improve SSRI treatment in some studies (Harvey and Balon, 1995; Trivedi et al., 2006a) but not consistently (Blier and Ward, 2003). Differences between pindolol and buspirone appear due to their differential antagonist or agonist activity at 5-HT1A receptors. For example, unlike buspirone, acute pindolol treatment potentiates citalopram-mediated increase in 5-HT in rats (Hjorth, 1996). However, buspirone has unique agonist activities that can differ from full agonists like 5-HT. Buspirone and its analog BMY7378 inhibited Gi2-dependent constitutive activity of the 5-HT1A receptor, while full agonists (5-HT, 8OH-DPAT) or antagonists WAY100635, pindolol and NAN-190 had little or no effect (Albert et al., 1999). In the raphe nuclei, buspirone recruits $\mathrm{Gi} 2$, Gi3, and Go to the 5-HT1A receptor and inhibits adenylyl cyclase, while $8 \mathrm{OH}$-DPAT only recruited Gi3 and did not inhibit forskolin-stimulated adenylyl cyclase (Valdizan et al., 2009). The preferential activity of buspirone in raphe cells may explain the efficacy of buspirone to decrease 5-HT synthesis in olfactory-bulbectomized rats (Watanabe et al., 2006). Other compounds that act at 5-HT1A receptors, such as atypical antipsychotics aripiprazole (Abilify) or SNRI milnacipran (Savella), can also ameliorate response to SSRIs. However, while these compounds desensitize the 5-HT1A autoreceptor (Mochizuki et al., 2002), they have other targets that can participate in their antidepressant actions. In addition it is important to note that drugs that indirectly target 5-HT neurons (Guiard et al., 2008) such as bupropion or $\alpha 2$-adrenergic receptor antagonists may also enhance response to SSRI response (Tremblay and Blier, 2006; Trivedi et al., 2006a; Blier et al., 2010). Thus, the concept of a multi-system therapeutic strategy appears to provide enhanced treatment response and remission rates compared to SSRI alone (Blier et al., 2010).

\section{TARGETING 5-HT1A GENE TRANSCRIPTION FOR THE TREATMENT OF DEPRESSION}

The inconsistent results using 5-HT1A agonists to augment or accelerate response to SSRIs, may be due to their limited ability to decrease presynaptic 5-HT1A receptor levels. In fact, effective treatment appears to require long-term adaptive changes in addition to rapid desensitization of 5-HT1A autoreceptors, such as reduced transcription of 5-HT1A autoreceptors or induction of post-synaptic 5-HT1A receptors. For example, it was recently shown that aripiprazole increases hippocampal and cortical 5-HT1A receptors (Han et al., 2009). This suggests that long-term activation of presynaptic 5-HT1A receptors might trigger transcriptional changes that follow the rapid initial desensitization of the receptors and lead to long-term alterations in 5-HT1A receptor levels. The recent finding that a 30\% transcription-mediated increase in 5-HT1A autoreceptors is sufficient to abolish response to chronic antidepressant treatment in adult mice (RichardsonJones et al., 2010), suggests that an ability to even slightly downregulate 5-HT1A autoreceptor expression could greatly improve SSRI response in treatment-resistant patients.

Additionally, it would be important to determine how 5-HT1A agonists affect the expression and activity of key transcriptional regulators of the 5-HT1A receptor gene. Recent findings suggested that alterations in Deaf1 occur both in raphe and prefrontal cortex of depressed females (Szewczyk et al., 2009; Goswami et al., 2010), suggesting that females may be more responsive to drugs that could upregulate Deaf1 expression. Up-regulation of Deaf-1 levels would be expected to repress presynaptic and induce post-synaptic 5-HT1A gene expression to increase serotonin neurotransmission in heterozygous or $\mathrm{C} / \mathrm{C}$ homozygous subjects. However, patients with the 5-HT1A G/G(-1019) genotype would be expected to be resistant since the G-allele does not respond to Deaf1.

Since depression is twice as frequent in females compared to males, gender-specific alterations in 5-HT1A autoreceptor expression could mediate an increased susceptibility. In female rats and serotonin transporter-deficient female mice, ovariectomy results in increased raphe 5-HT1A receptor RNA and binding (Bouali et al., 2003; Le Saux and Di Paolo, 2005) and increased anxiety behavior (Imwalle et al., 2005), while estrogen treatment reverses changes in 5-HT1A levels and anxiety, increasing raphe responsiveness (Abizaid et al., 2005). Similarly, estrogen receptor-beta knockout female mice display increased anxiety and reduced raphe 5-HT levels (Imwalle et al., 2005). In female rhesus macaques, ovariectomy leads to an increase in nuclear NFkB in 5-HT raphe neurons, while estrogen/progesterone reverses this (Bethea et al., 2006) and reduces 5-HT1A autoreceptor protein level (Henderson and Bethea, 2008), which could be driven by NFkB-response element in the 5-HT1A promoter. Thus estrogen appear to be protective for anxiety and negatively regulates 5-HT1A autoreceptor levels to enhance raphe activity, but the mechanisms of this regulation remain to be clarified.

Antidepressant treatments could also target cortical 5-HT1A receptors, which are reduced in depression. Down-regulation of Freud-1 or Freud-2 in post-synaptic regions could lead to an increase in 5-HT1A receptor RNA and normalize post-synaptic 5-HT1A receptor expression and restore response of post-synaptic neuron to 5-HT. Interestingly, Freud-1 RNA and protein was down-regulated in the prefrontal cortex of chronically stressed rats (Iyo et al., 2009), while 5-HT1A RNA level was increased, although 5-HT1A protein was reduced. Similarly in the prefrontal cortex of younger ( $<58$ years) depressed subjects (especially males), Freud-1 RNA and protein were decreased, while 5-HT1A receptor protein was also reduced (Szewczyk et al., 2010). Thus, despite increased 5-HT1A RNA other post-translational processes, such as receptor down-regulation, may reduce cortical 5-HT1A protein levels in depression. Interestingly, cortical Freud-1 levels were not altered by chronic treatment of macaques with SSRI, suggesting that other types of antidepressant treatments may be required to induce this effect. Alternately, Freud-1 activity could be reduced, for example by calcium mobilization, which inactivates Freud-1 (Ou et al., 2003). 


\section{CONCLUSION}

Alterations in pre- and post-synaptic 5-HT1A receptor RNA and protein expression in depression suggest that transcriptional dysregulation of the receptor is involved. Currently used 5-HT1A selective ligands are well known to induce desensitization of 5-HT1A receptors, but should be tested for their ability to alter 5-HT1A gene transcription.

\section{REFERENCES}

aan het Rot, M., Mathew, S. J., and Charney, D. S. (2009). Neurobiological mechanisms in major depressive disorder. CMAJ 180, 305-313.

Abizaid, A., Mezei, G., Thanarajasingam, G., and Horvath, T.L. (2005). Estrogen enhances light-induced activation of dorsal raphe serotonergic neurons. Eur. J. Neurosci. 21, 1536-1546.

Akimova, E., Lanzenberger, R., and Kasper, S. (2009). The serotonin-1A receptor in anxiety disorders. Biol. Psychiatry 66, 627-635.

Albert, P. R., Lembo, P., Storring, J. M., Charest, A., and Saucier, C. (1996). The 5-HT1A receptor: signaling, desensitization, and gene transcription. Neuropsychopharmacology 14, 19-25.

Albert, P. R., and Lemonde, S. (2004). 5-HT1A receptors, gene repression, and depression: guilt by association. Neuroscientist 10, 575-593.

Albert, P. R., Sajedi, N., Lemonde, S., and Ghahremani, M. H. (1999). Constitutive G(i2)-dependent activation of adenylyl cyclase type II by the 5-HT1A receptor. Inhibition by anxiolytic partial agonists. J. Biol. Chem. 274, 35469-35474.

Anttila, S., Huuhka, K., Huuhka, M., Rontu, R., Hurme, M., Leinonen, E., and Lehtimaki, T. (2007). Interaction between 5-HT1A and BDNF genotypes increases the risk of treatmentresistant depression. J. Neural Transm. 114, 1065-1068.

Artigas, F., Perez, V., and Alvarez, E. (1994). Pindolol induces a rapid improvement of depressed patients treated with serotonin reuptake inhibitors. Arch. Gen. Psychiatry 51, 248-251.

Barnes, N. M., and Sharp, T. (1999). A review of central 5-HT receptors and their function. Neuropharmacology 38 , 1083-1152.

Berney, A., Nishikawa, M., Benkelfat, C., Debonnel, G., Gobbi, G., and Diksic, M. (2008). An index of 5-HT synthesis changes during early antidepressant treatment: alpha-[(11)C]methyl-1tryptophan PET study. Neurochem. Int. 52, 701-708.

Berton, O., and Nestler, E. J. (2006). New approaches to antidepressant drug discovery: beyond monoamines. Nat. Rev. Neurosci. 7, 137-151.

Bethea, C. L., Reddy, A. P., and Smith, L. J. (2006). Nuclear factor kappa B in the dorsal raphe of macaques: an anatomical link for steroids, cytokines and serotonin.JPsychiatry Neurosci31, 105-114.

Bhagwagar, Z., Rabiner, E. A., Sargent, P. A., Grasby, P. M., and Cowen, P. J. (2004). Persistent reduction in brain serotonin1A receptor binding in recovered depressed men measured by positron emission tomography with [11C]WAY-100635. Mol. Psychiatry 9, 386-392.

Blier, P. (2003). The pharmacology of putative early-onset antidepressant strategies. Eur. Neuropsychopharmacol. 13, 57-66.

Blier, P., and Bergeron, R. (1995). Effectiveness of pindolol with selected antidepressant drugs in the treatment of major depression. J. Clin. Psychopharmacol. 15, 217-222.

Blier, P., Ward, H. E., Tremblay, P., Laberge, L., Hebert, C., and Bergeron, R. (2010). Combination of antidepressant medications from treatment initiation for major depressive disorder: a double-blind randomized study. Am. J. Psychiatry 167, 281-288.

Blier, P., and Ward, N. M. (2003). Is there a role for 5-HT(1A) agonists in the treatment of depression? Biol. Psychiatry 53, 193-203.

Boldrini, M., Underwood, M. D., Mann, J. J., and Arango, V. (2008). Serotonin-1A autoreceptor binding in the dorsal raphe nucleus of depressed suicides. J. Psychiatr. Res. 42, 433-442.

Bortolozzi, A., Amargos-Bosch, M., Toth, M., Artigas, F., and Adell, A. (2004). In vivo efflux of serotonin in the dorsal raphe nucleus of 5-HT1A receptor knockout mice. J. Neurochem. 88, 1373-1379.

Bouali, S., Evrard, A., Chastanet, M., Lesch, K. P., Hamon, M., and Adrien, J. (2003). Sex hormone-dependent desensitization of 5-HT1A autoreceptors in knockout mice deficient in the 5-HT transporter. Eur. J. Neurosci. 18, 2203-2212.

Burnet, P. W., Mead, A., Eastwood, S. L., Lacey, K., Harrison, P. J., and Sharp, T. (1995). Repeated ECS differentially affects rat brain 5-HT1A and 5-HT2A receptor expression. Neuroreport 6 , 901-904.

Czesak, M., Lemonde, S., Peterson, E. A., Rogaeva, A., and Albert, P. R. (2006). Cell-specific repressor or enhancer activities of Deaf-1 at a serotonin

Among the known transcriptional regulators of the 5-HT1A receptor, Deaf- 1 is a very attractive target due to its ability to repress presynaptic 5-HT1A expression, while inducing post-synaptic 5-HT1A receptors. Thus, identification of ligands or strategies that activate or induce Deaf- 1 could simultaneously target pre- and post-synaptic 5-HT1A receptor expression to increase serotonergic tone.

1 A receptor gene polymorphism. J. Neurosci. 26, 1864-1871.

Doris, A., Ebmeier, K., and Shajahan, P. (1999). Depressive illness. Lancet 354, 1369-1375.

Drevets, W.C., Thase, M.E., Moses-Kolko, E. L., Price, J., Frank, E., Kupfer, D. J. and Mathis, C. (2007). Serotonin-1A receptor imaging in recurrent depression: replication and literature review. Nucl. Med. Biol. 34, 865-877.

Duman, R.S. (2004). Role of neurotrophic factors in the etiology and treatment of mood disorders. Neuromol. Med. 5, 11-26.

Elena Castro, M., Diaz, A., del Olmo, E. and Pazos, A. (2003). Chronic fluoxetine induces opposite changes in G protein coupling at pre and postsynaptic 5-HT1A receptors in rat brain. Neuropharmacology 44, 93-101.

Fanelli, R. J., and McMonagle-Strucko, K. (1992).Alteration of 5-HT1A receptor binding sites following chronic treatment with ipsapirone measured by quantitative autoradiography. Synapse 12, 75-81.

Fava, M., and Kendler, K. S. (2000) Major depressive disorder. Neuron $28,335-341$.

Gordon, J. A., and Hen, R. (2004). The serotonergic system and anxiety. Neuromol. Med. 5, 27-40.

Goswami, D. B., May, W. L., Stockmeier, C. A., and Austin, M. C. (2010) Transcriptional expression of serotonergic regulators in laser-captured microdissected dorsal raphe neurons of subjects with major depressive disorder: sex-specific differences. $J$. Neurochem. 112, 397-409.

Greenwood, B. N., Foley, T. E., Day, H. E., Burhans, D., Brooks, L., Campeau, S., and Fleshner, M. (2005). Wheel running alters serotonin (5-HT) transporter, 5-HT(1A), 5-HT(1B), and alpha(1b)-adrenergic receptor mRNA in the rat raphe nuclei. Biol. Psychiatry 57, 559-568.

Greenwood, B. N., Foley, T. E., Day, H. E. Campisi,J.,Hammack, S.H., Campeau, S., Maier, S. F., and Fleshner, M. (2003). Freewheel running prevents learned helplessness/behavioral depression: role of dorsal raphe serotonergic neurons. J. Neurosci. 23, 2889-2898.

Gross, C.,Zhuang, X., Stark, K., Ramboz, S., Oosting, R., Kirby, L., Santarelli, L., Beck, S., and Hen, R. (2002). Serotonin1A receptor acts during development to establish normal anxiety-like behaviour in the adult. Nature 416, 396-400.

Guiard, B. P., El Mansari, M., Merali, Z., and Blier, P. (2008). Functional interactions between dopamine, serotonin and norepinephrine neurons: an invivo electrophysiological study in rats with monoaminergic lesions. Int. J Neuropsychopharmacol. 11, 625-639.

Hadjighassem, M. R., Austin, M. C., Szewczyk, B., Daigle, M., Stockmeier, C. A., and Albert, P. R. (2009). Human Freud-2/CC2D1B: a novel repressor of postsynaptic serotonin-1A receptor expression. Biol. Psychiatry 66, 214-222.

Han, M., Huang, X. F., du Bois, T. M., and Deng, C. (2009). The effects of antipsychotic drugs administration on 5-HT1A receptor expression in the limbic system of the rat brain. Neuroscience 164, 1754-1763.

Harvey, K. V., and Balon, R. (1995). Augmentation with buspirone: a review. Ann. Clin. Psychiatry 7, 143-147.

Heisler, L. K., Chu, H. M., Brennan, T. J., Danao, J. A., Bajwa, P., Parsons, L. H., and Tecott, L.H. (1998). Elevated anxiety and antidepressant-like responses in serotonin 5-HT1A receptor mutant mice. Proc. Natl. Acad. Sci. U.S.A. 95, 15049-15054.

Henderson, J. A., and Bethea, C. L. (2008). Differential effects of ovarian steroids and raloxifene on serotonin $1 \mathrm{~A}$ and $2 \mathrm{C}$ receptor protein expression in macaques. Endocrine. 33, 285-293.

Hjorth, S. (1996). (-)-Pindolol, but not buspirone, potentiates the citalopraminduced rise in extracellular 5-hydroxytryptamine. Eur. J. Pharmacol. 303, 183-186.

Hjorth, S., Bengtsson, H. J., and Milano, S. (1996). Raphe 5-HT1A autoreceptors, but not postsynaptic 5-HT1A receptors or beta-adrenoceptors, restrain the citalopram-induced increase in extracellular 5-hydroxytryptamine in vivo. Eur. J. Pharmacol. 316, 43-47.

Hornung, J. P. (2003). The human raphe nuclei and the serotonergic system. J. Chem. Neuroanat. 26, 331-343.

Imwalle,D.B.,Gustafsson,J.A., and Rissman, E. F. (2005). Lack of functional estrogen receptor beta influences anxiety behavior and serotonin content in female mice. Physiol. Behav. 84, 157-163.

Iyo,A.H., Kieran, N., Chandran, A., Albert, P. R., Wicks, I., Bissette, G., and Austin, 
M.C. (2009). Differential regulation of the serotonin 1 A transcriptional modulators five prime repressor element under dual repression- 1 and nucleardeformed epidermal autoregulatory factor by chronic stress. Neuroscience 163, 1119-1127.

Jacobsen, K. X., Vanderluit, J., Slack, R. S., and Albert, P.R. (2008). HES1 regulates 5-HT1A receptor gene transcription at a functional polymorphism: Essential role in developmental expression. Mol. Cell. Neurosci. 38, 349-358.

Jans, L. A., Riedel, W. J., Markus, C. R., and Blokland, A. (2007). Serotonergic vulnerability and depression: assumptions, experimental evidence and implications. Mol. Psychiatry 12, 522-543.

Kato,M.,Fukuda,T.,Wakeno,M., Okugawa, G., Takekita,Y., Watanabe, S., Yamashita, M., Hosoi, Y., Azuma, J., Kinoshita, T., and Serretti,A. (2009). Effect of 5-HT1A gene polymorphisms on antidepressant response in major depressive disorder. Am. J. Med. Genet. B Neuropsychiatr. Genet. 150B, 115-123.

Kishi, T., Tsunoka, T., Ikeda, M., Kawashima, K., Okochi, T., Kitajima, T., Kinoshita, Y., Okumura, T., Yamanouchi, Y., Inada, T., Ozaki, N., and Iwata, N. (2009). Serotonin 1A receptor gene and major depressive disorder: an association study and meta-analysis. J. Hum. Genet. 54, 629-633.

Kraus, M. R., Al-Taie, O., Schafer, A., Pfersdorff, M., Lesch, K. P., and Scheurlen, M. (2007). Serotonin-1A receptor gene HTR1A variation predicts interferon-induced depression in chronic hepatitis C. Gastroenterology 132, 1279-1286.

Kusserow, H., Davies, B., Hortnagl, H., Voigt, I., Stroh, T., Bert, B., Deng, D. R., Fink, H., Veh, R. W., and Theuring, F. (2004). Reduced anxiety-related behaviour in transgenic mice overexpressing serotonin $1 \mathrm{~A}$ receptors. Brain Res. Mol. Brain Res. 129, 104-116.

Lanfumey, L., Mongeau, R., CohenSalmon, C., and Hamon, M. (2008). Corticosteroid-serotonin interactions in the neurobiological mechanisms of stress-related disorders. Neurosci. Biobehav. Rev. 32, 1174-1184.

Lanzenberger, R. R., Mitterhauser, M., Spindelegger, C., Wadsak, W., Klein, N., Mien, L. K., Holik, A., Attarbaschi, T., Mossaheb,N.,Sacher,J., Geiss-Granadia, T., Kletter, K., Kasper, S., and Tauscher, J. (2007). Reduced serotonin-1A receptor binding in social anxiety disorder. Biol. Psychiatry 61, 1081-1089.

Le François, B., Czesak, M., Steubl, D., and Albert, P. R. (2008). Transcriptional regulation at a HTR1A polymorphism associated with mental illness. Neuropharmacology 55, 977-985.

Lemonde, S., Du, L., Bakish, D., Hrdina, P., and Albert, P. R. (2004a). Association of the C(-1019)G 5-HT1A functional promoter polymorphism with antidepressant response. Int. J. Neuropsychopharmacol. 7, 501-506.

Lemonde, S., Rogaeva, A., and Albert, P. R. (2004b).Cell type-dependent recruitment of trichostatin A-sensitive repression of the human 5-HT1A receptor gene. J. Neurochem. 88, 857-868.

Lemonde, S., Turecki, G., Bakish, D., Du, L., Hrdina, P. D., Bown, C. D., Sequeira, A., Kushwaha, N., Morris, S. J., Basak, A., Ou, X. M., and Albert, P. R. (2003). Impaired repression at a 5-hydroxytryptamine $1 \mathrm{~A}$ receptor gene polymorphism associated with major depression and suicide. $J$. Neurosci. 23, 8788-8799.

Le Poul, E., Boni, C., Hanoun, N., Laporte, A. M., Laaris, N., Chauveau, J., Hamon, M., and Lanfumey, L. (2000). Differential adaptation of brain 5-HT1A and 5-HT1B receptors and 5-HT transporter in rats treated chronically with fluoxetine. Neuropharmacology 39, 110-122.

Le Poul, E., Laaris, N., Doucet, E., Laporte, A. M., Hamon, M., and Lanfumey, L. (1995). Early desensitization of somato-dendritic 5-HT1A autoreceptors in rats treated with fluoxetine or paroxetine. Naunyn Schmiedebergs Arch. Pharmacol. 352, 141-148.

Le Saux, M., and Di Paolo, T. (2005). Changes in 5-HT1A receptor binding and G-protein activation in the rat brain after estrogen treatment: comparison with tamoxifen and raloxifene. J. Psychiatry Neurosci. 30, 110-117.

Lopez, J. F., Chalmers, D. T., Little, K. Y., and Watson, S. J. (1998). A.E. Bennett Research Award. Regulation of serotonin1A, glucocorticoid, and mineralocorticoid receptor in rat and human hippocampus: implications for the neurobiology of depression. Biol. Psychiatry 43, 547-573.

Lopez-Figueroa, A. L., Norton, C. S., Lopez-Figueroa, M. O., ArmelliniDodel, D., Burke, S., Akil, H., Lopez, J.F., and Watson, S. J. (2004). Serotonin 5-HT1A, 5-HT1B, and 5-HT2A receptor mRNA expression in subjects with major depression, bipolar disorder, and schizophrenia. Biol. Psychiatry $55,225-233$.

Mann, J. J. (2005). The medical management of depression. N. Engl. J. Med. 353, 1819-1834.

Mann, J. J., Brent, D. A., and Arango, V. (2001). The neurobiology and genetics of suicide and attempted suicide: a focus on the serotonergic system. Neuropsychopharmacology 24 , 467-477.

Martinez, D., Mawlawi, O., Hwang, D., Kent, J., Simpson, N., Parsey, R. V., Hashimoto, T., Slifstein, M., Huang, Y., Van Heertum, R., Abi-Dargham, A., Caltabiano, S., Malizia, A., Cowley, H.,
Mann, J. J., and Laruelle, M. (2000). Positron emission tomography study of pindolol occupancy of 5-HT(1A) receptors in humans: preliminary analyses. Nucl. Med. Biol. 27, 523-527.

Mathers, C. D., and Loncar, D. (2006) Projections of global mortality and burden of disease from 2002 to 2030 . PLoS Med. 3, e442. doi: 10.1371/journal.pmed.0030442.

Meltzer, C. C., Price, J. C., Mathis, C. A., Butters, M. A., Ziolko, S. K., MosesKolko, E., Mazumdar, S., Mulsant, B. H., Houck, P. R., Lopresti, B. J., Weissfeld, L. A., and Reynolds, C. F. (2004). Serotonin 1A receptor binding and treatment response in late-life depression. Neuropsychopharmacology 29, 2258-2265.

Millan, M. J. (2004). The role of monoamines in the actions of established and "novel" antidepressant agents: a critical review. Eur. J. Pharmacol. 500, 371-384.

Mochizuki, D., Hokonohara, T., Kawasaki, K., and Miki, N. (2002). Repeated administration of milnacipran induces rapid desensitization of somatodendritic 5-HT1A autoreceptors but not postsynaptic 5-HT1A receptors.J. Psychopharmacol. 16, 253-260.

Morley-Fletcher, S., Darnaudery, M., Mocaer, E., Froger, N., Lanfumey, L., Laviola, G., Casolini, P., Zuena, A. R., Marzano, L., Hamon, M., and Maccari, S. (2004). Chronic treatment with imipramine reverses immobility behaviour, hippocampal corticosteroid receptors and cortical 5-HT(1A) receptor mRNA in prenatally stressed rats. Neuropharmacology $47,841-847$.

Moses-Kolko, E. L., Wisner, K. L., Price, J. C., Berga, S. L., Drevets, W. C., Hanusa, B. H., Loucks, T. L., and Meltzer, C. C. (2008). Serotonin 1A receptor reductions in postpartum depression: a positron emission tomography study. Fertil. Steril. 89, 685-692.

Nash, J. R., Sargent, P. A., Rabiner, E. A., Hood, S. D., Argyropoulos, S. V., Potokar, J. P., Grasby, P. M., and Nutt, D. J. (2008). Serotonin 5-HT1A receptor binding in people with panic disorder: positron emission tomography study. Br. J. Psychiatry 193, 229-234.

Neff, C.D., Abkevich,V.,Packer,J.C., Chen, Y., Potter, J., Riley, R., Davenport, C., DeGrado Warren, J., Jammulapati, S. Bhathena, A., Choi, W. S., Kroeger, P. E., Metzger, R. E., Gutin, A., Skolnick, M. H., Shattuck, D., and Katz, D. A (2009). Evidence for HTR1A and LHPP as interacting genetic risk factors in major depression. Mol. Psychiatry 14, 621-630.

Nestler, E. J., and Carlezon, W. A. Jr. (2006). The mesolimbic dopamine reward circuit in depression. Biol. Psychiatry 59, 1151-1159.
Neumeister, A., Bain, E., Nugent, A. C., Carson, R.E., Bonne, O., Luckenbaugh, D. A., Eckelman, W., Herscovitch, P., Charney, D. S., and Drevets, W. C. (2004). Reduced serotonin type 1A receptor binding in panic disorder. $J$. Neurosci. 24, 589-591.

Newman-Tancredi, A., Chaput, C. Gavaudan, S., Verriele, L., and Millan, M. J. (1998). Agonist and antagonist actions of (-)pindolol at recombinant, human serotonin 1A (5-HT1A) receptors. Neuropsychopharmacology 18 , 395-398.

Ou, X. M., Jafar-Nejad, H., Storring, J. M., Meng, J. H., Lemonde, S., and Albert, P. R. (2000). Novel dual repressor elements for neuronal cell-specific transcription of the rat 5-HT1A receptor gene. J. Biol. Chem. 275, 8161-8168.

$\mathrm{Ou}, \mathrm{X}$. M., Lemonde, S., Jafar-Nejad, H., Bown, C. D., Goto, A., Rogaeva, A., and Albert, P. R. (2003). Freud-1: a novel calcium-regulated repressor of the 5-HT1A receptor gene. J. Neurosci. 23, 7415-7425.

Parks, C. L., Robinson, P. S., Sibille, E., Shenk, T., and Toth, M. (1998). Increased anxiety of mice lacking the serotonin 1 A receptor. Proc. Natl. Acad. Sci. U.S.A. 95, 10734-10739.

Parks, C. L., and Shenk, T. (1996). The serotonin 1a receptor gene contains a TATA-less promoter that responds to MAZ and Sp1. J. Biol. Chem. 271, 4417-4430.

Parsey, R. V., Olvet, D. M., Oquendo, M. A., Huang, Y. Y., Ogden, R. T., and Mann, J. J. (2006a). Higher 5-HT1A receptor binding potential during a major depressive episode predicts poor treatment response: preliminary data from a naturalistic study. Neuropsychopharmacology 31, 1745-1749.

Parsey, R. V., Oquendo, M. A., Ogden, R. T., Olvet, D. M., Simpson, N., Huang, Y. Y., Van Heertum, R. L., Arango, V., and Mann, J. J. (2006b). Altered serotonin $1 \mathrm{~A}$ binding in major depression: a [carbonyl-C-11]WAY100635 positron emission tomography study. Biol. Psychiatry 59, 106-113.

Portella, M. J., de Diego-Adelino, J., Puigdemont, D., Perez-Egea, R., Alvarez, E., Artigas, F., and Perez, V. (2009). Pindolol augmentation enhances response outcomes in first depressive episodes. Eur. Neuropsychopharmacol. 19, 516-519.

Rabiner, E. A., Bhagwagar, Z., Gunn, R. N., Cowen, P. J., and Grasby, P. M. (2004). Preferential 5-HT(1A) autoreceptor occupancy by pindolol is attenuated in depressed patients: effect of treatment or an endophenotype of depression? Neuropsychopharmacology 29, 1688-1698.

Ramboz, S., Oosting, R., Amara, D. A., Kung, H. F., Blier, P., Mendelsohn, M., 
Mann, J. J., Brunner, D., and Hen, R. (1998). Serotonin receptor 1A knockout: an animal model of anxietyrelated disorder. Proc. Natl. Acad. Sci. U.S.A. 95, 14476-14481.

Riad, M., Garcia, S., Watkins, K. C., Jodoin, N., Doucet, E., Langlois, X., el Mestikawy, S., Hamon, M., and Descarries, L. (2000). Somatodendritic localization of 5-HT1A and preterminal axonal localization of 5-HT1B serotonin receptors in adult rat brain. J. Comp. Neurol. 417, 181-194.

Riad, M., Watkins, K. C., Doucet, E., Hamon, M., and Descarries, L. (2001). Agonist-induced internalization of serotonin-1a receptors in the dorsal raphe nucleus (autoreceptors) but not hippocampus (heteroreceptors). J. Neurosci. 21, 8378-8386.

Riad, M., Zimmer, L., Rbah, L., Watkins, K. C., Hamon, M., and Descarries, L. (2004). Acute treatment with the antidepressant fluoxetine internalizes 5-HT1A autoreceptors and reduces the in vivo binding of the $P E T$ radioligand [18F]MPPF in the nucleus raphe dorsalis of rat. J. Neurosci. 24, 5420-5426.

Richardson-Jones, J. W., Craige, C. P., Guiard, B. P., Stephen, A., Metzger, K. L., Kung, H. F., Gardier, A. M., Dranovsky, A., David, D. J., Beck, S. G., Hen, R., and Leonardo, E. D. (2010). 5-HT(1A) autoreceptor levels determine vulnerability to stress and response to antidepressants. Neuron 65, 40-52.

Richer, M., Hen, R., and Blier, P. (2002). Modification of serotonin neuron properties in mice lacking 5-HT1A receptors. Eur. J. Pharmacol. 435, 195-203.

Rossi, D. V., Burke, T. F., McCasland, M., and Hensler, J. G. (2008). Serotonin-1A receptor function in the dorsal raphe nucleus following chronic administration of the selective serotonin reuptake inhibitor sertraline. J. Neurochem. 105, 1091-1099.

Santarelli, L., Saxe, M., Gross, C., Surget,A., Battaglia, F., Dulawa, S., Weisstaub, N., Lee, J.,Duman, R., Arancio, O., Belzung, C., and Hen, R. (2003). Requirement of hippocampal neurogenesis for the behavioral effects of antidepressants. Science 301, 805-809.

Sargent, P. A., Kjaer, K. H., Bench, C. J., Rabiner, E. A., Messa, C., Meyer, J., Gunn, R. N., Grasby, P.M., and Cowen, P. J. (2000). Brain serotonin 1 A receptor binding measured by positron emission tomography with [11C] WAY-100635: effects of depression and antidepressant treatment. Arch. Gen. Psychiatry 57, 174-180.

Savitz, J., Lucki, I., and Drevets, W. C. (2009). 5-HT(1A) receptor function in major depressive disorder. Prog. Neurobiol. 88, 17-31.
Serrats, J., Artigas, F., Mengod, G., and Cortes, R. (2004). An autoradiographic study of the influence of pindolol upon [35S] GTPgammaS binding in rat, guinea pig and human brain. Int. J. Neuropsychopharmacol. 7, 27-34.

Shen, C., Li, H., and Meller, E. (2002). Repeated treatment with antidepressants differentially alters 5-HT1A agonist-stimulated [35S] GTP gamma $\mathrm{S}$ binding in rat brain regions. Neuropharmacology 42, 1031-1038.

Shively, C. A., Friedman, D. P., Gage, H. D., Bounds, M. C., Brown-Proctor, C., Blair, J. B., Henderson, J. A., Smith, M. A., and Buchheimer, N. (2006). Behavioral depression and positron emission tomography-determined serotonin $1 \mathrm{~A}$ receptor binding potential in cynomolgus monkeys. Arch. Gen. Psychiatry 63, 396-403.

Sibug, R. M., Compaan, J. C., Meijer, O. C., Van der Gugten, J., Olivier, B., and De Kloet, E. R. (1998). Flesinoxan treatment reduces 5-HT1A receptor mRNA in the dentate gyrus independently of high plasma corticosterone levels. Eur. J. Pharmacol. 353, 207-214.

Sim-Selley, L. J., Vogt, L. J., Xiao, R., Childers, S. R., and Selley, D.E. (2000). Region-specific changes in 5-HT(1A) receptor-activated G-proteins in rat brain following chronic buspirone. Eur. J. Pharmacol. 389, 147-153.

Skolnick, P., Popik, P., and Trullas, R. (2009). Glutamate-based antidepressants: 20 years on. Trends Pharmacol. Sci. 30, 563-569.

Sotelo, C., Cholley, B., S., E. M., Gozlan, H., and Hamon, M. (1990). Direct immunohistochemical evidence of the existence of 5-HT1A autoreceptors on serotoninergic neurons in the midbrain raphe nuclei. Eur. J. Neurosci. 2, 1144-1154.

Stockmeier, C. A., Shapiro, L. A., Dilley, G. E., Kolli, T. N., Friedman, L., and Rajkowska, G. (1998). Increase in serotonin-1A autoreceptors in the midbrain of suicide victims with major depression-postmortem evidence for decreased serotonin activity. J. Neurosci. 18, 7394-7401.

Storring, J. M., Charest, A., Cheng, P., and Albert, P. R. (1999). TATA-driven transcriptional initiation and regulation of the rat serotonin 5-HT1A receptor gene. J. Neurochem. 72, 2238-2247.

Sullivan, G.M., Ogden, R. T., Oquendo, M. A., Kumar, J. S., Simpson, N., Huang, Y. Y., Mann, J. J., and Parsey, R. V. (2009). Positron emission tomography quantification of serotonin-1A receptor binding in medication-free bipolar depression. Biol. Psychiatry $66,223-230$

Sullivan, G.M., Oquendo, M.A., Simpson, N., Van Heertum, R. L., Mann, J.J., and
Parsey, R. V. (2005). Brain serotonin1A receptor binding in major depression is related to psychic and somatic anxiety. Biol. Psychiatry 58, 947-954.

Szewczyk, B., Albert, P. R., Burns, A. M., Czesak, M., Overholser, J. C., Jurjus, G. J., Meltzer, H. Y., Konick, L. C., Dieter, L., Herbst, N., May, W., Rajkowska, G., Stockmeier, C. A., and Austin, M. C. (2009). Gender-specific decrease in NUDR and 5-HT1A receptor proteins in the prefrontal cortex of subjects with major depressive disorder. Int. J. Neuropsychopharmacol. $12,155-168$.

Szewczyk, B., Albert, P. R., Rogaeva, A., Fitzgibbon, H., May, W., Rajkowska, G., Miguel-Hidalgo, J. J., Stockmeier, C. A., Woolverton, W. L., Kyle, P. B., Wang, Z., and Austin, M.C. (2010). Decreased expression of Freud-1/CC2D1A, a transcriptional repressor of the 5-HT1A receptor, in the prefrontal cortex of subjects with major depression. Int. J. Neuropsychopharmacol. (in press).

Tauscher, J., Bagby, R. M., Javanmard, M., Christensen, B. K., Kasper, S., and Kapur, S. (2001). Inverse relationship between serotonin 5-HT(1A) receptor binding and anxiety: a [(11)C] WAY-100635 PET investigation in healthy volunteers. Am. J. Psychiatry 158, 1326-1328.

Tremblay, P., and Blier, P. (2006). Catecholaminergic strategies for the treatment of major depression. Curr. Drug Targets 7, 149-158.

Trivedi, M.H., Fava, M., Wisniewski, S. R., Thase, M. E., Quitkin, F., Warden, D., Ritz, L., Nierenberg, A. A., Lebowitz, B D., Biggs, M. M., Luther, J. F., ShoresWilson, K., and Rush, A. J. (2006a). Medication augmentation after the failure of SSRIs for depression. $N$. Engl. J. Med. 354, 1243-1252.

Trivedi, M. H., Rush, A. J., Wisniewski, S. R., Nierenberg, A. A., Warden, D., Ritz, L., Norquist, G., Howland, R. H., Lebowitz, B., McGrath, P. J., Shores-Wilson, K., Biggs, M. M. Balasubramani, G. K., and Fava, M. (2006b). Evaluation of outcomes with citalopram for depression using measurement-based care in $\mathrm{STAR}^{\star} \mathrm{D}$ : implications for clinical practice. Am. J. Psychiatry 163, 28-40.

Trivedi, M. H., Hollander, E., Nutt, D. and Blier, P. (2008). Clinical evidence and potential neurobiological underpinnings of unresolved symptoms of depression. J. Clin. Psychiatry 69, 246-258.

Ustun, T. B., Ayuso-Mateos, J. L., Chatterji, S., Mathers, C., and Murray, C. J. (2004). Global burden of depressive disorders in the year 2000. Br. J. Psychiatry 184, 386-392.

Valdizan, E. M., Castro, E., and Pazos, A. (2009). Agonist-dependent modulation of G-protein coupling and transduction of 5-HT1A receptors in rat dorsal raphe nucleus. Int. J. Neuropsychopharmacol. 1-9.

Villafuerte, S. M., Vallabhaneni, K., Sliwerska, E., McMahon, F. J., Young, E. A., and Burmeister, M. (2009). SSRI response in depression may be influenced by SNPs in HTR1B and HTR1A. Psychiatr. Genet. 19, 281-291.

Walther, D. J., Peter, J.U., Bashammakh, S., Hortnagl, H., Voits, M., Fink, H., and Bader, M. (2003). Synthesis of serotonin by a second tryptophan hydroxylase isoform. Science 299, 76.

Watanabe, A., Hasegawa, S., Nishi, K., Nguyen, K. Q., and Diksic, M. (2006). Chronic buspirone treatment normalizes regional serotonin synthesis in the olfactory bulbectomized rat brain: an autoradiographic study. Brain Res. Bull. 69, 101-108.

Welner, S. A., De Montigny, C., Desroches, J., Desjardins, P., and Suranyi-Cadotte, B.E. (1989). Autoradiographic quantification of serotonin 1 A receptors in rat brain following antidepressant drug treatment. Synapse 4, 347-352.

Wong, D. T., Perry, K. W., and Bymaster, F. P. (2005). Case history: the discovery of fluoxetine hydrochloride (Prozac). Nat. Rev. Drug Discov. 4, 764-774.

Yevtushenko, O. O., Oros, M. M., and Reynolds, G. P. (2010). Early response to selective serotonin reuptake inhibitors in panic disorder is associated with a functional 5-HT1A receptor gene polymorphism. J. Affect Disord. $123,308-311$.

Young, S. N., and Leyton, M. (2002). The role of serotonin in human mood and social interaction. Insight from altered tryptophan levels. Pharmacol. Biochem. Behav. 71, 857-865.

Conflict of Interest Statement: The authors declare that the research was conducted in the absence of any commercial or financial relationships that could be construed as a potential conflict of interest.

Received: 12 April 2010; paper pending published: 05 May 2010; accepted: 10 May 2010; published online: 17 June 2010.

Citation: Albert PR and Le François B (2010) Modifying 5-HT1A receptor gene expression as a new target for antidepressant therapy. Front. Neurosci. 4:35. doi: 10.3389/fnins.2010.00035

This article was submitted to Frontiers in Neuropharmacology, a specialty of Frontiers in Neuroscience.

Copyright $(02010$ Albert and Le François. This is an open-access article subject to an exclusive license agreement between the authors and the Frontiers Research Foundation, which permits unrestricted use, distribution, and reproduction in any medium, provided the original authors and source are credited. 